\title{
Concentrations of selected toxic elements in ewe living near an environmentally loaded area of eastern part of Slovakia
}

\author{
Terézia Pošiváková',A-F, Rudolf Hromada ${ }^{2, E}$, Katarína Veszelits Laktičováá,E-F, Mária Vargová2,E-F, \\ Ĺuboš Korytár ${ }^{2, E}$, Jozef Švajlenka ${ }^{3, A-F}$, Miroslav Húska ${ }^{2, B}$, Elena Hatalová2,B, Ján Pošivák ${ }^{2, D-F}$, \\ Róbert Klein ${ }^{2, E}$ \\ 1 University of Veterinary Medicine and Pharmacy, Kosice, Slovak Republic \\ ${ }^{2}$ Technical Universities, Kosice, Slovak Republic \\ $A$ - research concept and design; $B$ - collection and/or assembly of data; $C$ - data analysis and interpretation; \\ $D$ - writing the article; $E$ - critical revision of the article; $F$ - final approval of article
}

\begin{abstract}
Pošiváková T, Hromada R, Laktičová KV, Vargová M, Korytár, Švajlenka J, Húska M, Hatalová E, Pošivák J, Klein R. Concentrations of selected toxic elements in ewe living near an environmentally loaded area of eastern part of Slovakia. Ann Agric Environ Med. 2017; 24(4): 667-670. doi: $10.26444 /$ aaem/75639
\end{abstract}

\begin{abstract}
Introduction and objective. Research focused on the monitoring of selected heavy metals in ewes' blood. Concentrations of selected toxic elements, lead, cadmium and zinc, in ewes living near an environmentally-loaded area, concerned 15 ewes (aged 3-4 years) in good physical condition, during the spring of 2014 and 2015 in the eastern part of Slovakia. The aim of the research was to determine the concentration of selected heavy metals and state the correlations of selected heavy metals in ewes' blood.

Materials and method. Within the period of 2 years, 15 ewe were evaluated. Ewes' blood samples were collected twice during the spring season from a farm located in area Spiš, eastern Slovakia, and then analysed for heavy metal contents. In the area under investigation, contamination with heavy metals was assumed as a result of intensive agricultural development and former mining activities. The level of selected heavy metals in the experimental group of animal blood was determined using an optical spectrophotometry.

Results. Statistical analyses were carried out using the Statistica programme. The significant differences between means were calculated by the statistical method of the non-parametric Mann-Whitney's U test. The statistical test experimental group of ewes in 2014 and 2015 confirmed the presence of selected heavy metals in ewes. The measured values of Cd $(P=0.0003), P b(P=0.0200)$ and $Z n(P=0.0018)$ showed significant differences when comparing the years 2014 and 2015.

Conclusion. The obtained and analysed blood samples confirmed the presence of selected heavy metals in ewes from area of Spiš in eastern Slovakia, which belongs the sub-region or is among the localities environmentally burdened. The conclusions are centred on the population's interest and concern for the environment, as well as on the preoccupation with factors that affect the satisfaction of basic needs, the local agricultural development and former mining activities.
\end{abstract}

\section{Key words}

biochemical marker, environment, heavy metal, health status, ewes

\section{INTRODUCTION}

The health and viability of agricultural animals is the basic requirement for their productivity and positive economic effect on the agricultural industry. The Spiš region and its adjacent areas are characterized by high mineral deposits. For centuries, this area was used for the mining and processing of ore. Heavy metals from industrial activities still affect the environment in this area which has impacts not only on the plants and animals, but also on human health [1]. Sheep are the most commonly kept livestock in this area due to the geographical conditions. Grazing sheep on contaminated grass at the foot of a hill can seriously affect their health status. Hazardous chemicals escape into the environment by a number of natural anthropogenic activities, and may cause adverse effects on human and animal health and the environment [2]. The interactions of the environment with

Address for correspondence: Terézia Pošiváková, University of Veterinary Medicine and Pharmacy in Kosice, Komenského 73, 04181 Košice, Slovak Republic

e-mail: terezia.posivakova@uvlf.sk

Received: 20.05.2017; accepted: 03.07.2017; first published: 07.09.2017 organisms or communities of organisms, with its physical, chemical and biological components, have been of great interest in the post-industrial period. The natural balance of ecosystems formed in the course of evolution is easily breached by various negative interferences. Many air pollutants, such as carbon monoxide (CO), sulphur dioxide (SO2), nitrogen oxides (NOx), heavy metals, and respirable particulate matter, differ in their chemical composition, reaction properties, emission, time of disintegration, and ability to diffuse over long or short distances [3]. Environmental pollution has both acute and chronic effects on an organism's health, affecting a number of different systems and organs [4]. Heavy metals include basic metal elements, such as lead, mercury, cadmium, silver, nickel, vanadium, chromium and manganese. They are natural components of the earth's crust, they cannot be degraded or destroyed, can be transported by air, and enter water and the human food supply through the food chain. In addition, they enter the environment through a wide variety of sources, including combustion, waste water and manufacturing facilities from industrial and agricultural activity. To a small extent, they enter human bodies where, 
as trace elements, they are essential for maintaining normal metabolic reactions, for example, $\mathrm{Zn}, \mathrm{Cu}, \mathrm{Co}, \mathrm{Fe}, \mathrm{Mn}$ and $\mathrm{Mo}$. However, at higher, although relatively low, concentrations they can become toxic [5-7]. Toxic elements are mainly As, $\mathrm{Cd}, \mathrm{Hg}$ and $\mathrm{Pb}$. Most heavy metals are dangerous because they tend to bio-accumulate in living organisms. Bioaccumulation means an increase in the concentration of a chemical in a biological organism over time, compared to the chemical's concentration in the environment $[8-10,24]$. Compounds accumulate in organisms and are stored faster than they are metabolized or excreted. In the obtained results, levels of metal in the ewes' blood were used as a non-destructive monitoring tool for metal exposure among important animal species in the food chain.

\section{MATERIALS AND METHOD}

The ewes used in research came from the area Spiš in eastern Slovakia. In the area under investigation, it was assumed that there was contamination by heavy metal as a result of intensive agricultural development and former mining activities. The experimental group consisted of $(n=15)$ ewes with no signs of disease. Ewe were kept in the farm year-round. They were approximately the same age, with an average live weight of $36 \mathrm{~kg}$. Blood was taken from the jugular vein into blood collection tubes by a veterinarian in the spring of 2014 and the spring of 2015. The blood was immediately centrifuged. Blood serum was stored at $-20^{\circ} \mathrm{C}$ until analysed. The aim of the experiment was to determine the concentration of selected heavy metals (lead, cadmium and zinc) in ewes' blood and to find the correlations between the observed selected heavy metal in blood. The analysed selected heavy metals were evaluated due to the increased occurrence of these metals in the concerned area, which have monitored in the past by the authors of the current article. The increased incidence of these heavy metals has been confirmed by the studies of several authors [1,23] who also monitored the target area. The concentrations of lead $(\mathrm{Pb})$ and cadmium $(\mathrm{Cd})$ in the experimental animals were determined using an inductively coupled plasma optical emission spectroscopy (ICP-OES) (PerkinElmer) OPTIMA 2100 DV. The concentration of zinc $(\mathrm{Zn})$ was determined using an atomic absorption spectrophotometer AAnalyst 100 (Perkin Elmer) ANALYST 100. The obtained results were statistically analysed by the method of the non-parametric Mann-Whitney's U test.

\section{RESULTS}

In the experimental group of 15 clinically healthy ewes the presence of selected heavy metals was confirmed in the blood of the animals. The measured values of $\mathrm{Cd}, \mathrm{Pb}$ and $\mathrm{Zn}$ showed that significant differences were found in comparing the years 2014 and 2015. In the measured levels of Cd, significant differences were found $(\mathrm{P}=0.0003)$, when comparing the years 2014 and 2015. The average level of Cd in 2014 (0.110 $\pm 0.035 \mu \mathrm{mol} / \mathrm{l})$ was lower than the average level of $\mathrm{Cd}$ in $2015(0.765 \pm 0.467 \mu \mathrm{mol} / \mathrm{l})$. Significant differences were also found $(\mathrm{P}=0.0200)$ when comparing the levels of $\mathrm{Pb}$ in 2014 and 2015. The average level of $\mathrm{Pb}$ in $2014(0.519 \pm 0.196$ $\mu \mathrm{mol} / \mathrm{l})$ was lower than the mean level of $\mathrm{Pb}$ in 2015 (0.703 $\pm 0.225 \mu \mathrm{mol} / \mathrm{l})$. The measured level of $\mathrm{Zn}$ in 2014 was found to be significantly different $(\mathrm{P}=0.0018)$ than the level of $\mathrm{Zn}$ in 2015. The average level of $\mathrm{Zn}$ in $2014(11.676 \pm 0.968 \mu \mathrm{mol} / \mathrm{l})$ was lower than that measured level of $\mathrm{Zn}$ in 2015 (13.405 \pm $1.488 \mu \mathrm{mol} / \mathrm{l})$. Figure 1 and Figure 3 show the concentrations of analysed heavy metals in the two years.

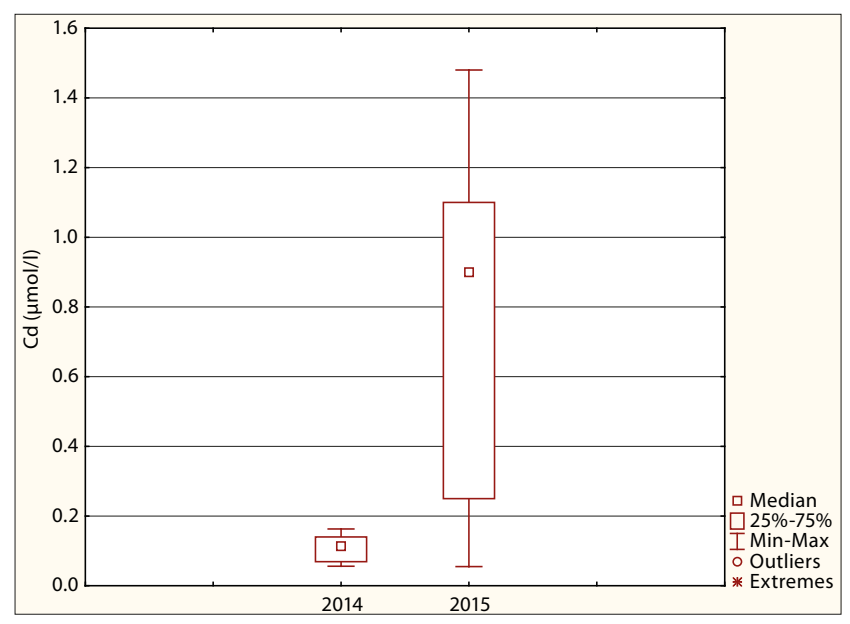

Figure 1. Concentrations of Cd in 2014 and 2015

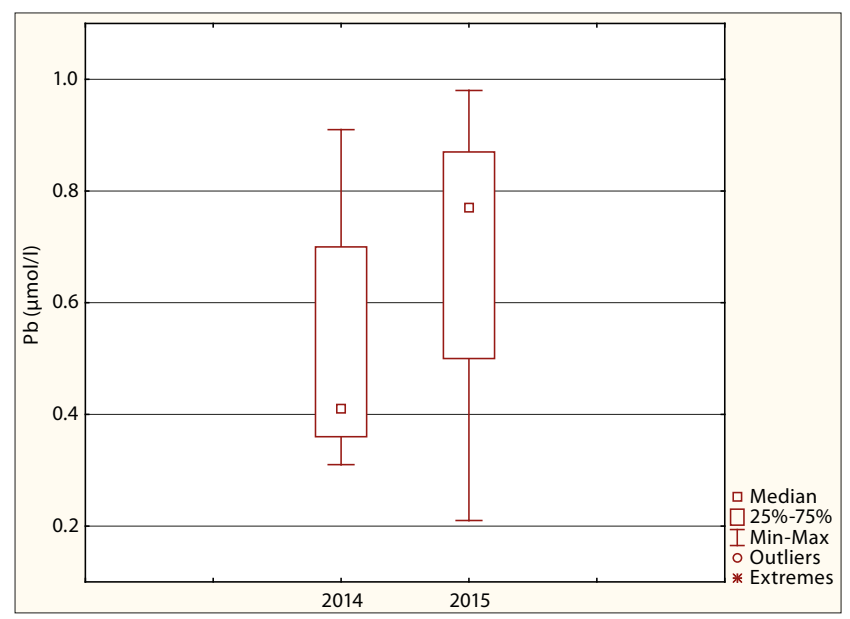

Figure 2. Concentrations of $\mathrm{Pb}$ in 2014 and 2015

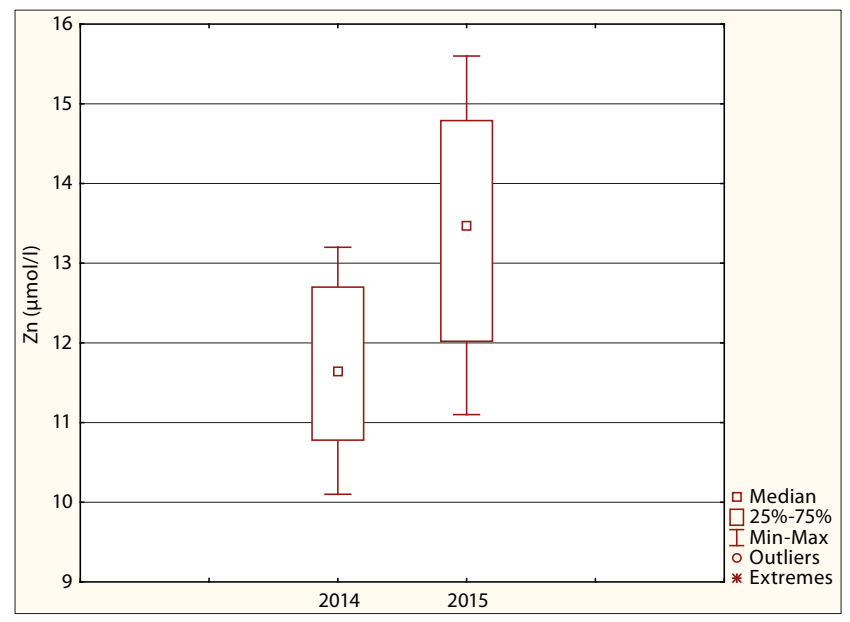

Figure 3. Concentrations of $\mathrm{Zn}$ in 2014 and 2015 


\section{DISCUSSION}

A similar analysis of selected heavy metal concentrations was dealt with by the authors Erman et al. [11] from the north-western region of Turkey. The measured values of $\mathrm{Cd}$ in $2014(0.110 \pm 0.035 \mu \mathrm{mol} / \mathrm{l})$ was almost equal to the maximum average values $\mathrm{Cd}$ found in the presented study $(0.101 \pm 0.019 \mu \mathrm{mol} / \mathrm{l})$. Erman et al. [11] reported lower average levels of $\mathrm{Pb}(0.246 \pm 0.009 \mu \mathrm{mol} / \mathrm{l})$ and $\mathrm{Zn}(1.758 \pm$ $0.178 \mu \mathrm{mol} / \mathrm{l})$, compared to the average values of $\mathrm{Pb}(0.519$ $\pm 0.196 \mu \mathrm{mol} / \mathrm{l})$ and $\mathrm{Zn}(11.676 \pm 0.968 \mu \mathrm{mol} / \mathrm{l})$ measured in 2014 by the authors of the current study. Lee et al. [12] had earlier reported the heavy metal contaminations in ewes' blood. The measured level of Cd in 2015 (0.765 \pm 0.467 $\mu \mathrm{mol} / \mathrm{l})$ in the current study was lower compared to the finding $(2.597 \mu \mathrm{mol} / \mathrm{l})$ by the named authors. Investigation of selected heavy metals in the blood of sheep has also been dealt with by Crivineanu et al. [13] in a region of southern Greece. The measured average values of $\mathrm{Pb}(0.519 \pm 0.196 \mu \mathrm{mol} / \mathrm{l})$, $\mathrm{Cd}(0.110 \pm 0.035 \mu \mathrm{mol} / \mathrm{l})$ and $\mathrm{Zn}(11.676 \pm 0.968 \mu \mathrm{mol} / \mathrm{l})$ found in in 2014 in the presented study were higher than the findings of named authors, which confirmed the presence of $\mathrm{Pb}(0.183 \mu \mathrm{mol} / \mathrm{l}), \mathrm{Cd}(0.086 \mu \mathrm{mol} / \mathrm{l})$ and $\mathrm{Zn}(1.758 \mu \mathrm{mol} / \mathrm{l})$ in the experimental group of ewes. The above-mentioned researches documented the fact that foreign authors mostly deal with the problem of heavy metals in related species of animals. In the Slovakian geographical location there is a lack of knowledge about the concentrations of heavy metals in the target animals; therefore, the current study is of great benefit in this research field.

Aliyu et al. and Póti et al. [14, 15], from very different continents of the world, from the West African sub-Saharan region and the northeast part of Hungary in Central Europe, analysed the concentration of heavy metals in ewes' milk. The concentration of heavy metals in the meat of sheep reported by Nkansah et al. [16], from Pakistan region Perveen et al. [17], investigated the heavy metals $\mathrm{Na}, \mathrm{Cu}, \mathrm{Mn}$ and $\mathrm{Cr}$ in powdered milk and processed milk samples, while Jaffer et al. [18] reported the levels of 12 metals (Ca, K, Na, Mg, Fe, Mn, $\mathrm{Zn}, \mathrm{Cd}, \mathrm{Cr}, \mathrm{Pb}, \mathrm{Co}$ and $\mathrm{Ni}$ ) in 19 different imported brands of unexpired and expired canned dry milk. The environmental impact on agriculture varies dependi9ng on the wide variety of industrial activities, agricultural practices and production practices of the system used by the farmers around the world. The connection between heavy metals and health status is a significant factor in terms of harm to health status of humans and animals.

Contaminated sites of several areas in eastern Slovakia has been confirmed by studies dealing with the monitoring of heavy metals in soils and water resources that are closely connected with the occurrence of heavy metals in living organisms. Škultéty [19] from the Department of Landscape Engineering in Nitra, examined the heavy metals in the Košice-Prešov region which is a loaded area, and confirmed the over-limit values of $\mathrm{Cu}$, As and $\mathrm{Hg}$ in the Hornád basin and river Torysa. These findings were also confirmed by Kročková, and Bodiš and Rapant [20,21] who processed the data in the sector indicator report of quality requirements of environmental components, which exceeded the group of synthetic substance indicators of $\mathrm{As}, \mathrm{Cd}, \mathrm{Cu}, \mathrm{Pb}$, and $\mathrm{Zn}$ in environmentally loaded areas in regions of Slovakia in the nationwide assessment. In the Smolník estuary, the monitoring reported a significant excess of $\mathrm{Zn} 188.83 \mu \mathrm{g} / \mathrm{l}$
Since the final consumers of products of animal origin are humans, careful protection of the environment can increase the quality of these foods, and ultimately, the health status of the consumer.

Bennett and Balvanera [23] support the claims by the authors of thios article about the occurrence of environmental burdens in the Spiš region as a consequence of particular former mining activities. The above-mentioned authors have elaborated on the monitoring report on the Spiš region area in which they documented the elevated values of heavy metals $\mathrm{Zn}$ and $\mathrm{Cd}$ in the environmental components in water and soil. This authors also reported that the elevated values of heavy metals pose a serious threat to the environment and the health of organisms. Dietzová and Labancová [1] have also reported that for centuries the localities of the Spiš region have benefited from the processing of ores used mainly for copper production. Emissions from the production have thus affected the surrounding environment to the present day, and has impacted not only on plants and animals, but also on human health. The presented study on the effects of heavy metals on animals' blood supplements the findings of mentioned authors and scientific research in the target area.

The presented study focused on investigating the concentration of heavy metals in the blood of monitored animals as the one of the main environmental factors in this locality. The overall state of the environmental pollutants in the target location is documented through the monitoring of other environmental components, for example, water, soil and plants. These, components, however, were not examined, but knowledge about them was mentioned in the Discussion section.

\section{CONCLUSIONS}

Increased amounts of heavy metals in the bodies of living organisms represent a stress factor which causes many physiological changes and result in inhibiting the growth of organisms to the point of extinction. With regards to the negative anthropogenic environmental impacts, the toxic contamination of foreign substances and monitoring of health and of various pathological reactions in animal populations, the food chain is of particular relevance and importance. For these reasons, the concentration of selected heavy metals in objective species of animals were analysed as an important indicator for the environment. The obtained and analysed blood samples confirmed the presence of selected heavy metals in ewes from Spiš in eastern Slovakia, which is a sub-region belonging to or is among localities with an environmental burden. Similar scientific studies support the findings of the presented study.

\section{REFERENCES}

1. Dietzová Z, Labancová J. Impact of emissions an incinerator TKO on the quality of air, soil, water and health of residents of surrounding communities, 2007; 50.

2. Kampa M, Castanas E. Human health effects of air pollution. Environ Pollut. 2008; 151: 362-367.

3. Jarup L. Hazards of heavy metal contamination. Br Med Bull. 2003; 68: $167-182$.

4. Rao DL. Heavy metals causing toxicity in humans, animals and environment. JCHPS. 2014; 3: 172-174.

5. Llobet JM, Falco G, Casas C, et al. Concentrations of Arsenic, Cadmium, Mercury and Lead in common foods and estimated daily Intake by 
children, adolescents, adult and seniors of Catalonia, Spain. J Agric Food Chem. 2003; 51: 838-842.

6. Olchowik G, Widomska J, Tomaszewski M, Gospodarek M, Tomaszewska M, Jagiełło-Wójtowicz E. The influence of lead on the biomechanical properties of bone tissue in rats. Ann Agric Environ Med. 2014; 21: 278-281.

7. Babčan S, Khun M, Ševc J. The toxicity of heavy metals Environment. Geochemical atlas of the Slovak Republic. 1999; 1: 74-145.

8. Peng J, Song Y, Yuan P, Cui X, Qiu GJ. The remediation of heavy metals contaminated sediment Hazard Mater. J Hazard Mater. 2009; 2: 633-640.

9. Goldman RL. Ecosystem Services, How People Benefit from Nature. Environment 2010; 9: 12-20.

10. Erman MO, Kayar A, Kiziler AR, et al. Determination of levels of some essential (iron, copper, zinc) and toxic (lead, cadmium) metals in the blood of sheep and in samples of water, plants and soil in northwest Turkey. Vet Arhiv. 2005; 75: 359-368.

11. Lee HJ, Jones GB. Interactions of selenium, cadmium and copper in sheep. Aust J Agric Res. 1976; 27: 447-52.

12. Crivineanu V, Leonidis A, Goran GV, et al. Correlations between some metals levels in the environment and their blood concentration in sheep farmed in Thessaloniki province. Lucrări științifice medicină veterinară. 2010; 2: 147-152.

13. Aliyu OA, Faruruwa MD, Abdu AH. Seasonal Evaluation of Mineral Elements, Heavy Metals, Essential Amino Acids, Proximate Compositions and Pesticides in Goat Milk. WJAC. 2015; 3: 1-9.
14. Póti P, Pajor F, Bodnár Á, et al. Accumulation of some heavy metals $\mathrm{Pd}, \mathrm{Cd}$ and $\mathrm{Cr}$ in milk of grazing sheep in North-east Hungary. JMBFS. 2012; 2: 389-394.

15. Nkansah MA, Ansah JK. Determination of Cd, Hg, As, $\mathrm{Cr}$ and $\mathrm{Pb}$ level in meat from the Kumasi Central Abattoir. IJSRP. 2014; 4: 1-4.

16. Perveen $\mathrm{K}, \mathrm{Zeb} \mathrm{A}$. Investigation of $\mathrm{Na}, \mathrm{Cu}, \mathrm{Mn}$ and $\mathrm{Cr}$ in powdered and processed milk samples available in Pakistan. Jour Zhejiang Sci. 2007; 8: 555-559.

17. Jaffer M, Shagand MH, Shaheen N. Determination of 12 metals in 19 different imported brands of expired and unexpired canned dry milk. J Nutr Sci. 2004; 34: 65-70.

18. Škultéty P. Influence of environmental loads on land character. SAŽP. $2015 ; 278-285$.

19. Kročková B. Contamination of agricultural soils. SAŽP. 2016; 1-2.

20. Bodiš D, Rapant S. Environmental geochemistry and environmental geochemical mapping of the Slovak Republic. Slovak Geological Magazine. 2000; 6: 5-16.

21. Wiek A, Withycombe L, Redman CH, et al. Moving Forward on Competence in Sustainability Research and Problem Solving. Environment 2011; 4: 187-191.

22. Bennett EM, Balvanera $P$. The future of production systems in a globalized world. Front Ecol Environ. 2007; 5: 191-198.

23. Vlčkova R, Valocky I, Lazar G, Sopková D, Maraček I. Histological and ultrasonographic monitoring of folliculogenesis in puerperal ewes after spring lambing. Acta Vet Brno. 2008; 77(1): 65-72. 